DOI 10.15290/cnisk.2017.02.03.04

DR BEATA GOWORKO-SKŁADANEK

orcid.org/0000-0002-8689-1646

Uniwersytet $w$ Białymstoku

\title{
Obchody Międzynarodowego Dnia Kobiet w Rosji w latach 1913-1991
}

\section{Streszczenie}

Po raz pierwszy Dzień Kobiet był obchodzony w Petersburgu w 1913 r. Dopiero w 1921 r. na mocy decyzji II Komunistycznej Konferencji Kobiet postanowiono uczcić Międzynarodowy Dzień Kobiet w dniu 8 marca. Nowe święto zostało ustanowione na cześć udziału kobiet w demonstracji w Petersburgu w dniu 23 lutego (8 marca) 1917 r. Od 1922 r. 8 marca był obchodzony jako święto proletariackie, skupiające się wokół Rosyjskiej Partii Komunistycznej (bolszewickiej), związków zawodowych i haseł budowania nowego ładu społecznego. W dwudziestą rocznicę zakończenia Wielkiej Wojny Ojczyźnianej 8 marca został uznany dniem wolnym od pracy na mocy dekretu Prezydium Rady Najwyższej ZSRS. Do czasu pierestrojki państwowym obchodom dnia 8 marca towarzyszyły hasła polityczne. Po upadku Związku Sowieckiego dzień 8 marca pozostał na liście dni świątecznych Federacji Rosyjskiej i zarazem dniem wolnym od pracy.

Słowa kluczowe: Międzynarodowy Dzień Kobiet, 8 marca, rewolucja lutowa, rewolucja październikowa, równouprawnienie, emancypacja 


\title{
THE CELEBRATION OF INTERNATIONAL WOMEN'S DAY IN RUSSIA IN 1913-1991
}

\begin{abstract}
International Women's Day was celebrated for the first time in St. Petersburg in 1913. It was only after the $2^{\text {nd }}$ Communist Women's Conference's decision in 1921 to proclaim March 8th International Women's Day. The new holiday was established in honor of the women's participation in a demonstration in St Petersburg on the $8^{\text {th }}$ of March 1917. From 1922 it was celebrated as a proletarian feast, closely tied to the Russian Communist Party (Bolsheviks) and trade unions with their slogans on building a new social order. On the $20^{\text {th }}$ anniversary of the end of the Great Patriotic War, the Presidium of the Supreme Soviet of the USSR declared the $8^{\text {th }}$ of March as work free day. By the time of perestroika, the state celebrations of International Women's Day were accompanied by political propaganda. After the fall of the Soviet Union, the $8^{\text {th }}$ of March remained on the list of official public holidays of the Russian Federation.

Keywords: International Women's Day, March 8, February Revolution, October Revolution, equality, emancipation

\section{* \\ Wprowadzenie}

Międzynarodowy Dzień Kobiet po raz pierwszy wyłonił się $z$ działalności ruchów robotniczych na przełomie XIX i XX stulecia w Ameryce Północnej i Europie. To socjaliści zaczęli po raz pierwszy mówić o tym święcie. W czasie Międzynarodowej Konferencji Socjalistycznej w 1910 r., która odbyła się w Kopenhadze, ustanowiono Dzień Kobiet, by uczcić ruch praw kobiet i budować poparcie dla uzyskania dla nich powszechnych praw wyborczych. W wyniku inicjatywy kopenhaskiej Międzynarodowy Dzień Kobiet był obchodzony po raz pierwszy w Austrii, Danii, Niemczech i Szwajcarii ${ }^{1}$.
\end{abstract}

1 UN, International Women's Day. 8 march. History of the Day, [Dostep: 05.08.2017]. Dostepny w World Wide Web: <http://bit.ly/11bzIEp>. 
Z ruchem socjalistycznym nieodmiennie łączy się postać Klary Zetkin, niemieckiej socjalistki, która wzywała do stworzenia tego „wyjątkowego dnia”, głosząc równocześnie potrzebę zapewnienia kobietom praw wyborczych. Odwoływała się do tego święta, nazywając je nie tylko świętem pracowników, ale także wszystkich kobiet, które w jej ocenie stanowiły niezależna kategorię społeczną ${ }^{2}$.

W latach 1913-1914 w tym dniu odbywały się protesty przeciwko I wojnie światowej. Tak też było w 1917 r. w Rosji. Demonstracja ostatniej niedzieli lutego, w której kobiety domagały się „chleba i pokoju”, przerodziła się w walkę o ich wyzwolenie polityczne i równouprawnienie. To, że rewolucja lutowa rozpoczęła się w Międzynarodowym Dniu Kobiet, jest niezaprzeczalne. Jednak w dyskusjach na temat tego wydarzenia umniejsza się rzeczywista rolę kobiet jako aktywnej grupy społecznej walczącej o swoje prawa. W tradycyjnych opracowaniach historycznych możemy znaleźć informacje, zgodnie $z$ którymi kobiety były głównie zainteresowane realizacja potrzeb ekonomicznych. Jeżeli w wydarzeniach tamtego okresu w ogóle przypisuje się im jakąkolwiek rolę, to zwykle taka, że nie były świadomymi podmiotami politycznymi i, domagając się chleba, spontanicznie doprowadziły do zamieszek. Demonstracjom kobiet, które wywołały rewolucję lutowa, a do których doszło w dniu Międzynarodowej Solidarności Kobiet, ich udziałowi jako kobietom-pracownicom przypisuje się mniejszą rolę niż mężczyznom-pracownikom, którzy je wspierali ${ }^{3}$.

W polskich opracowaniach historycznych odnoszacych się do tego okresu trudno znaleźć wzmianki na temat kobiet i roli, jaką odegrały. Dlatego też, opisując na łamach niniejszego artykułu wydarzenia tamtych dni, posłużono się wyłącznie literaturą rosyjskojęzyczna, sięgając zarówno do opracowań naukowych, jak i popularnonaukowych. Współczesne opracowania rosyjskojęzyczne, w przeciwieństwie do tych tradycyjnych, eksponują rolę kobiet oraz akcentuja ich udział nie tylko w rewolucjach w Rosji w 1917 r., ale przede wszystkim w walce o prawa polityczne. Po-

\footnotetext{
2 R. Ratčajld, Neposlušnye ženŝiny i russkie revolûcii 1917 g., „Ženŝina v rossijskomobŝestve" 2017, No. 2 (83), s. 37.

3 Ibidem.
} 
nieważ Dzień Kobiet w Rosji stał się świętem politycznym i za takie uchodził do czasu pierestrojki, poniżej opisano hasła, pod jakimi był organizowany, zwłaszcza w okresie dwudziestolecia międzywojennego. Tu także, $z$ uwagi na brak tej tematyki w polskiej literaturze, korzystano wyłącznie $z$ opracowań rosyjskojęzycznych.

\section{Pierwsze obchody Dnia Kobiet w Rosji}

Popularny już w państwach zachodnich Międzynarodowy Dzień Kobiet po raz pierwszy był obchodzony w Rosji w Petersburgu w 1913 r. pod hasłem walki o równość praw ekonomicznych i politycznych dla kobiet. W odpowiedzi na petycję skierowana do mera władze wyraziły zgodę na zorganizowanie „Poranka naukowego na temat problemów kobiet” („Научного утра по женскому вопросу"). 2 marca 1913 r. (według starego porządku, według nowego byłby to 15 marca 1913 r.) ${ }^{4}$ w budynku Giełdy Zbożowej Kałasznikowa (Калашниковская хлебная биржа) na ul. Połtawy odbyła się konferencja naukowa. W obecności 1,5 tys. osób prezentowano polityczne odczyty, w których mowa była o wysokich kosztach utrzymania, podnoszono potrzebę zapewnienia kobietom prawa do głosowania oraz świadczeń ze strony państwa w okresie macierzyństwa.

\section{Walka o prawa kobiet w tle rewolucji 1917 r.}

Aktywność kobiet w Rosji w tamtym okresie była duża. 23 lutego (8 marca) 1917 r. w Petersburgu pracownice zakładów tekstylnych $z$ dzielnicy Wyborg zebrały się na spotkaniu na temat „Wojna, drożyzna i położenie kobiet”. Nie tylko robotnice, ale także kobiety stojace $\mathrm{w}$ kolejkach za chlebem i nafta były nastawione

\footnotetext{
4 Dekret SNKRSFSR „O vvedenii v Rossijskoj respublike zapadnoevropejskogo kalendarâ", [Dostęp: 04.08.2017]. Dostępny w World Wide Web: <http://bit. ly/2vzWdOC>.
} 
bardzo bojowo 5 i otwarcie wyrażały swoje stanowisko. Negatywne nastawienie i odpowiednia agitacja spowodowały, że tysiące kobiet wyszło na ulice, domagając się „chleba i pokoju”. Także wzdłuż głównej ulicy Petersburga przeszedł pochód zorganizowany przez socjalistów żądających chleba i równych praw dla kobiet. Szacuje się, że tego dnia na ulice wyszło ok. 90 tys. pracowników z pięćdziesięciu zakładów. Demonstracje te były wstępem do rewolucji lutowej. Po czterech dniach car Mikołaj II abdykował ${ }^{6} .3$ marca 1917 r. Rząd Tymczasowy opublikował swój program, w którym nie znalazła się żadna wzmianka o „równouprawnieniu” i przyznaniu kobietom praw politycznych. Początkowo Rząd Tymczasowy i Piotrogrodzka Rada Delegatów Robotniczych i Żołnierskich (Временное правительство и Советы рабочих и солдатских депутатов) uznały żądania uczestnictwa kobiet w wyborach za przedwczesne i nieistotne, a tym samym nie chciały ich wspierać. Reakcja aktywistek Ligi Równości Kobiet polegała na zwróceniu uwagi kobiet i ogółu społeczeństwa na ten problem. Liga zaapelowała do kobiet, by te rozpoczęły walkę o wyzwolenie polityczne, przeprowadzała też wiece, których harmonogram pojawił się w prasie ${ }^{7}$.

19 marca 1917 r. w Petersburgu odbyła się kolejna demonstracja, w której udział wzięło 40 tys. kobiet, ponad dziewięćdziesiąt organizacji kobiecych, domagających się możliwości pełnego uczestnictwa w wyborach. Były to nie tylko pracownice fabryk, ale także studentki Kursów Bestużewskich, lekarki, nauczycielki oraz przedstawicielki inteligencji. Demonstracji towarzyszyły takie hasła jak: „Miejsce kobiet w Zgromadzeniu Ustawodawczym” (Место женщины в Учредительном собрании!), „Wojna do zwycięskie-

\footnotetext{
5 I. Alferova, „Ženskij vopros” v teorii i praktike bol'ševizma (pervoe desâtiletie sovetskoj vlasti. 1917-1927 gg.), Brânsk 2011, s. 60.

6 Meždunarodnyj ženskij den', FGBU „Prezidentskaâ biblioteka imeni B.N. El'cina”, 2009-2017, [Dostęp: 05.08.2017]. Dostępny w World Wide Web: <http://bit. ly/2wkSBkA>; Meždunarodnyj ženskij den' 8 marta, Glavnaâ Sovetskaâ istoričeskaâ ènciklopediâ Mvat-Mekk, Izdatel'stvo „Direkt-Media”, [Dostęp: 05.08.2017]. Dostępny w World Wide Web: <http://bit.ly/2wkVmlZ>.

7 Seminar IC NŽF „IZ istorii rossijskogo ženskogodviženiâ. 8 marta - den' solidarnosti trudâsîhsâženŝin”, [Dostęp: 05.08.2017]. Dostępny w World Wide Web: <http://bit.ly/2iF7481>.
} 
go końca” (Война до победного конца) ${ }^{8}$, „Wolna kobieta w wolnej Rosji” (Свободная женщина в свободной России!), „Bez udziału kobiet prawo głosowania nie jest powszechne!” (Без участия женщин избирательное право не всеобщее!) ${ }^{9}$. Demonstracja przeszła z siedziby Rady Miejskiej mieszczącej się na Newskim Prospekcie w centrum miasta do siedziby Dumy Państwowej, do Pałacu Taurydów. W niezadaszonym samochodzie, który przejeżdżał przez kolumny demonstrantek, stały przywódczynie P. Szyszkina-Jawein (ginekolog $z$ zawodu i prezes Rosyjskiej Ligi Równości Kobiet) i W. Figner, które podjęły się negocjacji z Rządem Tymczasowym i kierownictwem Sowietów ${ }^{10}$. W imieniu demonstrantów zmusiły przewodniczacego Rady Nikola Czcheidze i przewodniczącego Dumy Michaiła Rodzianko, aby odpowiedzieli na wniosek przyznania kobietom prawa do głosowania. Szyszkina-Jawein zwróciła się do przewodniczącego Rady w tych słowach:

W zasadach będacych podstawa przyszłego rządu, ogłoszono zniesienie wszystkich ograniczeń klasowych, religijnych i narodowych, ale zapomniano o zniesieniu wszelkich ograniczeń dotyczących kobiet. Proponuje się zwołanie Konstytuanty w wyborach powszechnych, równych i tajnych, ale zapomina się wspomnieć o równych prawach dla kobiet i mężczyzn. (...) I tak, pamiętając przymierze naszych zagranicznych sióstr, my przyszłyśmy wam powiedzieć, że rosyjska kobieta domaga się praw człowieka, które jej, jako człowiekowi przysługują. Konstytuanta, która będzie reprezentować tylko jedna połowę populacji, w pewnym sensie nie będzie mogła być traktowana jako wyraziciel woli całego narodu, ale tylko jego połowy ${ }^{11}$.

Za zgodą księcia Gieorgija E. Lwowa, szefa Rządu Tymczasowego, udało się zrealizować tę prośbę. Kobiety otrzymały pozy-

\footnotetext{
A. Lozinskaâ, N. Nefedova, „Brosajte ruž'â i prisoedinâjtes' $k$ nam”, Kak ženŝiny ustroili Fevral'skuû revolûciû, [Dostęp: 06.08.2017]. Dostępny w World Wide Web: $<$ http://bit.ly/2gm6X01>.

9 V Peterburge - mnogotysâčnye demonstracii ženŝin, gorod zapolnen vojskami, [Dostęp: 10.08.2017]. Dostępny w World Wide Web: <http://bit.ly/2vnRPWR>.

10 R. Ratčajld, op. cit., s. 40.

11 V Peterburge..., <http://bit.ly/2vnRPWR>.
} 
tywną odpowiedź od liderów i Rządu Tymczasowego, a także deputowanych Petersburskiego Związku Robotników i Żołnierzy ${ }^{12}$.

Uchwała Rządu Tymczasowego z 15 kwietnia 1917 r. o przeprowadzeniu wyborów powszechnych do rad miejskich i o zarzadzaniu obwodami miejskimi (О производстве выборов гласных городских дум и об участковых городских управмениях) oraz Tymczasowy regulamin o przeprowadzeniu jawnych wyborów do rad miejskich (Временные правима о производстве выборов гласных городских дум) nadały prawo głosu wszystkim mieszkańcom miast w wieku 20 lat, bez względu na płeć czy narodowość, niezależnie od statusu ekonomicznego i czasu przebywania w mieście (ust. 3). Spowodowało to wzrost liczby wyborców w Piotrogrodzie 115 razy, a w Moskwie 130 razy i wyniosła ona około 1,4 oraz $1,2 \mathrm{mln}$ osób $^{13}$. Nowa ordynacja wyborcza była najbardziej demokratyczna w historii Rosji, która poczyniła duży krok do przodu, wyprzedzając wiele rozwiniętych państw Europy Zachodniej. W tym okresie wybory powszechne odbywały się już w Anglii, Francji, Szwajcarii, Belgii, Norwegii, Hiszpanii, Portugalii, Bułgarii, Stanach Zjednoczonych i Austrii. W żadnych $z$ tych państw kobiety nie mogły jednak uczestniczyć bezpośrednio w wyborach ${ }^{14}$. Dzięki wprowadzonym zmianom w prawie kobiety osiąnęły równouprawnienie w sferze politycznej. 20 lipca 1917 r. rząd zatwierdził decyzję o przyznaniu prawa głosu wszystkim kobietom, które ukończyły 20. rok życia. Rosja stała się pierwszą na świecie potęga, w której kobiety mogły głosować na równi $z$ mężczyznami ${ }^{15}$.

Julia Demidenko, zastępca dyrektora badań Państwowego Muzeum Historii Sankt Petersburga, twierdzi, że rewolucja lutowa swój początek zawdzięcza gospodyniom domowym, które wyszły na ulice, aby zaprotestować przeciwko trudnej sytuacji w Petersburgu

\footnotetext{
12 R. Ratčajld, op. cit., s. 40.

13 L. Pisar'kova, Moskovskaâ gorodskaâ izbiratel'naâ sistema v 1862-1917 gg., [Dostęp: 09.08.2017]. Dostępny w World Wide Web: <http://bit.ly/2wZoiCn>; Û. Krasovskaâ, Pravovaâ osnova deâtel'nosti gorodskih dum vesnoj-letom 1917 goda, Âroslavskaâ gosudarstvennaâ medicinskaâ akademiâ, [Dostęp: 11.08.2017]. Dostępny w World Wide Web: <http://bit.ly/2iFmF71>.

14 Ibidem.

15 A. Lozinskaâ, N. Nefedova, op. cit., <http://bit.ly/2iFvrlE>.
} 
spowodowanej brakami żywności i długimi kolejkami za chlebem, w których głównie stały kobiety. Początkowo ich żądania nie miały charakteru politycznego, gdyż domagały się tylko chleba i żywności dla dzieci obrońców ojczyzny ${ }^{16}$.

Bezsprzeczny jest jednak fakt, że rankiem 23 lutego $1917 \mathrm{r}$. na ulice wyszły robotnice i gospodynie domowe, wspierane następnie przez robotników, a wieczorem demonstracje ogarnęły już kilka dzielnic miasta ${ }^{17}$. Aleksandra Kołłontaj w czasopiśmie „Работница” napisała później: My pracownice, jako pierwsze $w$ dniu rosyjskiej rewolucji podniosłyśmy Czerwony sztandar, my jako pierwsze w Dniu Kobiet wyszłyśmy na ulice (Mь, работнищы, первые в дни русской революиии подняли Красное знамя, мы первые в Женский день вышли на улииу) ${ }^{18}$.

\section{Prawa kobiet}

We wrześniu 1917 r. Rosjanki otrzymały prawo do głosowania i kandydowania do najwyższego organu ustawodawczego kraju, Konstytuanty, na podstawie przyjętej 20 czerwca 1917 r. przez Rząd Tymczasowy uchwały w sprawie wyborów do Konstytuanty, które weszło w życie 11 września 1917 r. Zgodnie z treścią uchwały,

Konstytuanta składa się $z$ członków wybieranych przez naród na zasadzie powszechności, bez różnicy płci, równego prawa wyborczego, w wyborach bezpośrednich i tajnym głosowaniu, z zastosowaniem reprezentacji proporcjonalnej ${ }^{19}$.

Po rewolucji październikowej 1917 r. nadszedł czas na zagwarantowanie pozycji kobiet $\mathrm{w}$ materii konstytucyjnej. W sowiec-

\footnotetext{
${ }^{16}$ E. Danilevich, Vsë zavarili domohozâjki? Kak ženŝiny stali predvestnicami revolûcii, „Argumenty i Fakty” [online], 2017, No. 10, [Dostęp: 14.08.2017]. Dostępny w World Wide Web: <http://bit.ly/2Bre2m2>.

17 Ibidem.

18 A. Kollontaj, Naši zadači. Maj 1917 g., „Rabotnica” 1917, No. 1-2, s. 4 [w:] A. Kollontaj, Izbrannye stat'i i reči, Moskva 1972.

19 Postanovlenie Vremennogopravitel'stva ot 20 iûlâ 1917 g., Ob utverždenii razdela i položeniâ o vyborah vučreditel'noe sobranie, [Dostęp: 15.08.2017]. Dostępny w World Wide Web: <http://bit.ly/2vzPAf1>.
} 
kiej konstytucji z 1918 r. został zawarty przepis w całości poświęcony równości kobiet i mężczyzn ${ }^{20}$. Zabieg zrównania praw kobiet i mężczyzn miał na celu faktyczne zaangażowanie kobiet w budowę socjalizmu. Państwowa ideologia komunistyczna stała się symbolem emancypacji, a niewolnictwo kobiet zostało uznane za główna twierdzę burżuazji ${ }^{21}$.

\section{Obchody Dnia Kobiet w dwudziestoleciu międzywojennym}

W 1919 r. obchody dnia 8 marca odbyły się pod hasłem „Wszystko dla zwycięstwa Czerwonego Frontu!”. Ponieważ wrogowie kontrrewolucji byli przedstawiani jako wrogowie zewnętrzni i okupanci próbujący zapobiec triumfowi sprawiedliwości, na wszystkich wiecach zachęcano kobiety do uczestnictwa w walce $z$ wrogiem. Aleksandra Michajłowna Kołłontaj twierdziła, że:

Tylko przy udziale aktywnego żeńskiego proletariatu możliwe jest przeprowadzenie wszystkich wielkich przedsięwzięć socjalnych zaplanowanych przez Partię Komunistyczna. Tylko przy aktywnym wsparciu ze strony robotnic jest możliwe, aby zdobyć decydujące zwycięstwo nad ciemnymi siłami wrogów ludu pracującego, tylko przy świadomym udziale pracownic w walce między „czerwonymi” i „białymi”, która przyspieszy proces obumierania starego świata i ułatwi budowę fundamentu społecznego, na którym wyzwolona klasa robotnicza będzie mogła zbudować nowa, jasną przyszłość komunistycznego gmachu ${ }^{22}$.

Jak twierdzi B. Uspenskaya, Kołłontaj była jedna z niewielu marksistek i marksistów, którzy wątpili w automatyczne rozwiąza-

\footnotetext{
20 Zob. B. Goworko-Składanek, Obraz rosyjskich kobiet $w$ życiu publicznym $i$ politycznym na tle wszechrosyjskich sondaży przeprowadzonych przez Levade i VCIOM w latach 2005-2016, „Czasopismo Naukowe Instytutu Studiów Kobiecych” 2016, nr 1, s. 124-125.

${ }^{21}$ N. Kozlova, Meždunarodnyj ženskij den' 8 marta kakinstrument formirovaniâ sovetskoj političeskojkul'tury, „Ženŝina v rossijskomobŝestve” 2011, No. 1, s. 37. 22 I. Govrâkov, Istoriâ prazdnika 8 marta v publicistike Aleksandry Kollontaj, „Mediaal'manah" 2014, No. 5, s. 87.
} 
nie problemu kobiet przez rewolucję socjalistyczną ${ }^{23}$. Bolszewickie aktywistki podkreślały, że głównym zadaniem ruchu robotniczego kobiet jest emancypacja społeczna, pełne i ostateczne zwycięstwo nad wszystkimi wrogami klasy robotniczej. Dopiero potem będzie można rozmawiać o rozwiazaniu konkretnych problemów kobiet rodziny, produkcji i innych. Dzień Kobiet w 1920 r. był już obchodzony pod zupełnie nowym hasłem „Wszystko dla bezkrwawego zwycięstwa frontu pracy! Wszyscy pracuja, żeby go uczcić!”24.

W 1921 r. na mocy decyzji 2. Komunistycznej Konferencji Kobiet postanowiono uczcić Międzynarodowy Dzień Kobiet w dniu 8 marca. Nowe święto zostało ustanowione na cześć udziału kobiet $\mathrm{w}$ demonstracji w Piotrogrodzie w dniu 23 lutego (8 marca) 1917 r. Zdaniem komunistów udział kobiet w jednym $z$ wydarzeń poprzedzajacych rewolucję lutową, w wyniku której obalono monarchię, był bardzo ważny ${ }^{25}$.

Od 1922 r. 8 marca był obchodzony jako święto proletariackie. Był dniem kobiet pracujacych, a jego głównym hasłem było zjednoczenie robotników. Skupiał się wokół Komunistycznej Partii Rosyjskiej i związków zawodowych, walki z głodem i bezrobociem wśród kobiet. Na wsiach obchody święta 8 marca miały na celu nakłonienie kobiet do nauki na kursach rolniczych. Komitet Centralny Komunistycznej Partii Rosyjskiej i Centralny Departament Pracy stwierdziły, że:

To nie jest święto tylko niektórych pracownic. Cały proletariat jest zainteresowany wyzwoleniem kobiet pracujacych od wieloletniego bezprawia, a zatem Komunistyczna Międzynarodówka wzywa świadomych pracowników wszystkich klas do wspierania żądań pracujących kobiet, aby pomóc w osiagnięciu tych środków, któ-

\footnotetext{
${ }^{23}$ E. Marčenko, Ženskoe prostranstvo $v$ tradicionnoj kul'ture i v predstavleniâh ideologov RKP(b), „Vestnik Severo-Kavkazskogo gosudarstvennogo tehničeskogo universiteta" 2007, No. 2 (11), s. 67.

${ }^{24}$ I. Govrâkov, op. cit., s. 87.

25 A. Arhipov, Povsej Rossii prodavali i „darili” cvety inostrannogo proishoždeniâ!, [Dostęp: 19.08.2017]. Dostępny w World Wide Web: <http://bit.ly/2vzWTUa>. Ministerstvo obrazovaniâ i nauki Rossijskoj Federacii, Meždunarodnyj ženskij den', [Dostęp: 19.08.2017]. Dostępny w World Wide Web: <http:/ / bit.ly/2xIIFkw>.
} 
re poprawią sytuację kobiet pracujących i będą chronić ich prawa $i$ interesy ${ }^{26}$.

Głównym hasłem 8 marca 1923 r. wznoszonym przez centralne i lokalne organy partii było podniesienie poziomu społeczno-politycznego i kulturowego oraz kwalifikacji zawodowych pracujących kobiet. Tego samego roku ogłoszono także tydzień ochrony macierzyństwa i niemowlęctwa. Również 8 marca 1923 r. świętowano uroczyście zakończenie szkół przez uczestniczki pierwszej edycji dokształcania kobiet w celu eliminacji analfabetyzmu. W 1924 r. Międzynarodowy Dzień Kobiet był obchodzony w duchu pamięci po zmarłym Leninie i rozpatrywaniu jego słów, $z$ których wynikało, że sowiecki rząd może kontynuować rozpoczęte dzieło tylko pod warunkiem, że znajdzie ono poparcie wśród milionów, a nie setek kobiet w Rosji. Poza politycznymi hasłami wysuwano także inne: „Koniec z kuchenna niewola!!”, „Niech żyje publiczna gastronomia!”, „Pracownico! Wyzwól się z kuchennych opresji!”. Od kobiety oczekiwano, że swoje siły i swój czas będzie poświęcać nie tylko rodzinie i domowi, ale też pracom użytecznym dla społeczeństwa - przy produkcji czy w gospodarstwie rolnym ${ }^{27}$.

$\mathrm{Na}$ początku lat dwudziestych XX w. 8 marca zmienił się w święto symbolizujace jedność robotników i robotnic w walce o budowę nowego społeczeństwa. Święto to nie różnicowało kobiet i mężczyzn. Dopiero w latach trzydziestych stało się bardziej kobiece $^{28}$. Zdaniem Natalii Lenivichiny w latach 1920-1930 nastapiły radykalne zmiany w życiu rosyjskich kobiet. Nawet biorąc pod uwagę błędy, wady i nadużycia popełnione w rozwiązywaniu kwestii „kobiecych” w ZSRS, należy uznać, że wiele osiagnięto. Kobiety otrzymały prawa polityczne i obywatelskie, do końca lat dwudziestych osiagnięto wysoki poziom skolaryzacji kobiet. Do połowy lat trzydziestych XX w. ponad 9 mln kobiet pracowało w przedsię-

\footnotetext{
${ }^{26}$ N.O. Lenivichina, Meždunarodnyj ženskij den'v Sovetskoj Rossii (Na materialah nižnevolžskogo regiona 20-h gg. XX v.), „Izvestiâ Volgogradskogo gosudarstvennogo pedagogičeskogo universiteta” 2016, No. 2 (106), s. 197-198.

27 Ibidem, s. 199.

28 I. Govrâkov, op. cit., s. 88.
} 
biorstwach i instytucjach, co stanowiło 35\% ogółu pracowników i urzędników ${ }^{29}$.

Zdaniem N. Kozlovej od końca lat dwudziestych XX stulecia w ZSRS Międzynarodowy Dzień Kobiet stał się fundamentem nowego typu kultury płci, podstawa nowej polityki w zakresie płci. „Kobieta - robotnica - gospodyni domowa - matka” (Женщина-paботница-домохозяйка-мать) - to był nowy zestaw ról społecznych wyznaczonych przez państwo dla kobiet. Obraz sowieckiej kobiety przedstawianej 8 marca łączył się $z$ propagandą dumy sowieckiej i był dowodem postępu. Obchody 8 marca przyczyniły się do mitologizacji i uwielbienia kobiet będacych przedmiotem zainteresowania państwa sowieckiego ${ }^{30}$.

\section{Obchody Dnia Kobiet po II wojnie światowej}

Po II wojnie światowej Dekretem Prezydium Rady Najwyższej ZSRS z 8 maja 1965 r. Międzynarodowy Dzień Kobiet obchodzony 8 marca ustanowiono dniem wolnym od pracy od 1966 r.,

aby upamiętnić wybitne zasługi sowieckich kobiet w budowie komunizmu, w obronie ojczyzny podczas Wielkiej Wojny Ojczyźnianej, ich heroizmu i bezinteresowności na froncie i na jego tyłach, oraz również zwrócić uwagę na ogromny wkład kobiet w umacnianie przyjaźni między narodami i walkę o pokój ${ }^{31}$.

Od tego czasu dzień ten przebiegał w oparciu o świąteczno-oficjalny rytuał. Podczas państwowych uroczystości przedstawiano założenia polityki państwowej wobec kobiet. Po okresie pierestrojki święto to nabrało zupełnie innego znaczenia ${ }^{32}$. Niegdyś obecne hasła polityczne utraciły znaczenie. Obecnie 8 marca jest

\footnotetext{
29 N.O. Lenivichina, op. cit., s. 202.

30 N. Kozlova, op. cit., s. 38.

${ }^{31}$ Prezidentskaâ biblioteka, Meždunarodnyj ženskij den', [Dostęp: 10.08.2017]. Dostępny w World Wide Web: <http://bit.ly/2xtvmVD>.

${ }^{32}$ Meždunarodnyj ženskij den', [Dostęp: 20.08.2017]. Dostępny w World Wide Web: <http://bit.ly/2vAbAXo>.
} 
świętem wszystkich rosyjskich kobiet, obchodzonym bez żadnych podtekstów politycznych ${ }^{33}$.

Po upadku Związku Sowieckiego dzień 8 marca pozostał na liście dni świątecznych Federacji Rosyjskiej. W dzisiejszych czasach Międzynarodowy Dzień Kobiet obchodzony jest także w krajach Wspólnoty Niepodległych Państw: Azerbejdżanie, Gruzji, Kazachstanie, Kirgistanie, Mołdowie, Tadżykistanie (od 2009 r. $z$ inicjatywy prezydenta znane także jako Dzień Matki ${ }^{34}$ ), Turkmenistanie, na Ukrainie i Białorusi. W Uzbekistanie obchodzony jest jako Dzień Matki, a w Armenii w dniu 7 kwietnia jako Dzień Macierzyństwa i Urody ${ }^{35}$.

Zgodnie $z$ postanowieniem art. 112 Kodeksu Pracy ${ }^{36} 8$ marca w Federacji Rosyjskiej jest w dalszym ciagu dniem wolnym od pracy.

\section{Zakończenie}

Święto Kobiet obchodzone 8 marca w Rosji sowieckiej wpisywało się w państwową ideologię komunistyczną, pod którego szyldem głoszone były polityczne hasła. Do czasu II wojny światowej było świętem proletariackim pracujacych mas, a nie tylko samych kobiet. Symbolem wspólnej walki robotników i robotnic w budowie nowego społeczeństwa. Państwo przypisało kobietom nowe role społeczne. Początek tego okresu zaznaczył się także w historii otrzymaniem przez kobiety praw politycznych i obywatelskich. Po II wojnie światowej 8 marca został uznany dniem wolnym od pracy,

\footnotetext{
${ }_{33}$ Ministerstvo obrazovaniâ i nauki Rossijskoj Federacii, Meždunarodnyj ženskij den', [Dostęp: 20.08.2017]. Dostępny w World Wide Web: <http://bit.ly/2xIIF$\mathrm{kW}>$.

${ }^{34}$ RIA Novosti, Prazdnovanie Meždunarodnogo ženskogo dnâv 2015 godu, [Dostęp: 20.08.2017]. Dostępny w World Wide Web: <http://bit.ly/2wP1MwC>.

35 Ministerstvo obrazovaniâ i nauki Rossijskoj Federacii, Meždunarodnyj ženskij den', [Dostęp: 20.08.2017]. Dostępny w World Wide Web: <http://bit.ly/2xIIF$\mathrm{kw}>$.

36 Trudovoj kodeks Rossijskoj Federacii ot 30.12.2001, N 197-FZ (red. ot 03.07.2016) (s izm. i dop., vstup. v silu s 01.01.2017), [Dostęp: 21.08.2017]. Dostępny w World Wide Web: <http://bit.ly/2wP4cvj>.
} 
a jego uroczystym państwowym obchodom towarzyszyły w dalszym ciagu hasła polityczne. Dopiero po pierestrojce święto to nabrało zupełnie innego wydźwięku.

\section{Bibliografia}

\section{Zasoby internetowe}

Arhipov Andrej, Povsej Rossii prodavali i „darili” cvety inostrannogo proishoždeniâ!, [Dostęp: 19.08.2017]. Dostępny w World Wide Web: $<$ http:// bit.ly/2vzWTUa>.

Danilevich Elena, Vsë zavarili domohozâjki? Kak ženŝiny stali predvestnicami revolûcii, „Argumenty i Fakty” [online], 2017, No. 10, [Dostęp: 14.08.2017]. Dostępny w World Wide Web: <http://bit.ly/2Bre2m2>.

Dekret SNKRSFSR, O vvedenii v Rossijskoj respublike zapadnoevropejskogo kalendarâ, [Dostęp: 04.08.2017]. Dostępny w World Wide Web: $<$ http://bit.ly/2vzWdOC>.

Krasovskaâ Ûlia, Pravovaâ osnova deâtel'nosti gorodskih dum vesnoj-letom 1917 goda, Âroslavskaâ gosudarstvennaâ medicinskaâakademiâ, [Dostęp 11.08.2017]. Dostępny w World Wide Web: <http://bit.ly/2iFmF71>.

Lozinskaâ Anna, Nefedova Natalia, „Brosajte ruž'â $i$ prisoedinâjtes' $k$ nam", Kak ženŝiny ustroili Fevral'skuû revolûciû, [Dostęp 06.08.2017]. Dostępny w World Wide Web: <http://bit.ly/2gm6X01>.

Meždunarodnyj ženskij den', [Dostęp: 20.08.2017]. <http://bit.ly/2vAbAXo>.

Meždunarodnyj ženskij den' 8 marta, Glavnaâ Sovetskaâ istoričeskaâ ènciklopediâ Mvat-Mekk, Izdatel'stvo „Direkt-Media”, [Dostęp: 05.08.2017]. Dostępny w World Wide Web: <http://bit.ly/2wkVmlZ>. Meždunarodnyj ženskij den', FGBU „Prezidentskaâbiblioteka imeni B.N. El'cina", 2009-2017, [Dostęp 05.08.2017]. Dostępny w World Wide Web: <http://bit.ly/2wkSBkA>.

Ministerstvo obrazovaniâ i nauki Rossijskoj Federacii, Meždunarodnyj ženskij den', [Dostęp: 19.08.2017]. Dostępny w World Wide Web: $<$ http://bit.ly/2xIIFkw>. 
Pisar'kova Lûbov', Moskovskaâ gorodskaâ izbiratel'naâ sistema v 18621917 gg., [Dostęp: 09.08.2017]. Dostępny w World Wide Web: <http:/ / bit.1y/2wZoiCn>.

Postanovlenie Vremennogopravitel'stva ot 20 iûlâ 1917 g., Ob utverždenii razdela i položeniâ o vyborah vučreditel'noe sobranie, [Dostep: 15.08.2017]. Dostepny w World Wide Web: <http://bit. ly $/ 2 \mathrm{vzPAf} 1>$.

Prezidentskaâ biblioteka, Meždunarodnyj ženskij den', [Dostęp: 10.08.2017]. Dostępny w World Wide Web: <http://bit.ly/2xtvmVD>. RIA Novosti, Prazdnovanie Meždunarodnogo ženskogo dnâv 2015 godu, [Dostęp: 20.08.2017]. <http://bit.ly/2wP1MwC>.

Seminar IC NŽF „Iz istorii rossijskogo ženskogodviženiâ. 8 marta-den'solidarnosti trudâsihsâženŝin”, [Dostęp: 05.08.2017]. Dostępny w World Wide Web: <http://bit.ly/2iF7481>.

Trudovoj kodeks Rossijskoj Federacii ot 30.12.2001 N 197-FZ (red. ot 03.07.2016) (s izm. i dop., vstup. v silu s 01.01.2017), [Dostęp: 21.08.2017]. Dostępny w World Wide Web: <http://bit.ly/2wP4cvj>.

$V$ Peterburge - mnogotysâčnye demonstracii žensin, gorod zapolnen vojskami, [Dostęp: 10.08.2017]. Dostępny w World Wide Web: <http:// bit.ly/2vnRPWR>.

\section{Opracowania}

Alferova Irina, „Ženskij vopros” v teorii i praktike bol'ševizma (pervoe desâtiletie sovetskoj vlasti. 1917-1927 gg.), Brânsk : Kursiv, 2011, ISBN 978-5-89592-127-2.

Goworko-Składanek Beata, Obraz rosyjskich kobiet $w$ życiu publicznym $i$ politycznym na tle wszechrosyjskich sondaży przeprowadzonych przez Levade i VCIOM w latach 2005-2016, „Czasopismo Naukowe Instytutu Studiów Kobiecych”2016, nr 1, s. 123-137, ISSN 2451-3539.

Govrâkov Igor, Istoriâ prazdnika 8 marta v publicistike Aleksandry Kollontaj, „Mediaal'manah” 2014, No. 5, s. 84-89, ISSN 1992-4631.

Lenivichina Natalia, Meždunarodnyj ženskij den'v Sovetskoj Rossii (Na materialah nižnevolžskogo regiona 20-h gg. XX v.), „Izvestiâ Volgogradskogo gosudarstvennogo pedagogičeskogo universiteta” 2016, No. 2 (106), s. 196-203, ISSN 1815-9044. 
Kozlova Natalia, Meždunarodnyj ženskij den' 8 marta kak instrument formirovaniâ sovetskojpolitičeskoj kul'tury, „Ženŝina v rossijskomobŝestve" 2011, No. 1, s. 36-44, ISSN 1992-2892.

Kollontaj Aleksandra, Naši zadači. Maj 1917 g., „Rabotnica” 1917 г., No. 1-2, s. 4 [w:] Kollontaj Aleksandra, Izbrannye stat'i $i$ reči, Moskva : Politizdat, 1972.

Marčenko Evdokija, „Ženskoe prostranstvo”. Vtradicionnoj kul'ture i v predstavleniâh ideologov RKP(b), „Vestnik Severo-Kavkazskogogosudarstvennogo tehničeskogo universiteta” 2007, No. 2 (11), s. 67-71, ISSN 2307-907X.

Ratčajld Rošel, Neposlušnye ženŝiny i russkie revolûcii 1917 g., „Ženŝina v rossijskomobŝestve" 2017, No. 2 (83), s. 35-44, ISSN 1992-2892. 